\title{
$\mathrm{OECD}$ 개발원조위원회(DAC) 주요규범 분석을 통한 국내 해양수산 공적개발원조(ODA) 발전방향 연구
}

\author{
함기영* $\cdot$ 민영훈**十 \\ * 선박안전기술공단 경영본부, ** 선박안전기술공단 녹색성장실
}

\section{A Study for Improvement of Korea's ODA in the Scope of Maritime Affairs and Fisheries through Analysis on Norms of OECD DAC}

\author{
Gi-Young Ham $^{*} \cdot$ Young-Hun $\mathrm{Min}^{* * \dagger}$ \\ *, ** Korea Ship Safety Technology Authority, Incheon, 406-840, Korea
}

\begin{abstract}
요 약 : 본 연구에서는 우리나라 공적개발원조(ODA)를 통한 개발도상국 지원 현황 및 해양수산부문 ODA 지원 현황을 정량적으로 분 석하였다. 또한 $\mathrm{OECD}$ 개발원조위원회(DAC)의 주요규범 및 국제 $\mathrm{ODA}$ 지원 방향에 관한 문헌 조사 및 정성적 자료 분석을 통해 향후 우 리나라 해양수산부문 ODA가 나아갈 방향 등을 제시하였다. 본 논문은 현재 우리나라 전체 ODA 규모가 지속적으로 증가함에도 불구하고 해양안전 혹은 수산 등과 관련된 ODA 규모가 답보상태에 머물러 있는 것에 착안, 향후 해양수산부문 $\mathrm{ODA}$ 규모 증대를 위해 정책적으로 취해야 할 방향에 대해 제언하였다.
\end{abstract}

핵심용어 : 개발도상국, 개발원조위원회, 경제협력개발기구, 공적개발원조, 해양수산

Abstract : In this paper, the volume of ODA of Korea to developing countries has been analysed quantitatively based on statistical information, compared with Korea's ODA in the scope of the maritime industry. Thereafter, norms and policies of ODA in OECD DAC and trends of ODA in international societies have been examined through literature and qualitative researches so that possible ways to forward in Korea's ODA have been proposed. Hence, in this paper it $h$ as been recognized that the volume of ODA related with the Korean maritime industry has been standing still as the before despite tremendous increase of total volume of Korea's ODA. for last 10 years. Consequently, the paper would like to propose possible measures that might been taken by the Korean government to raise the volume of ODA related with the maritime industry.

Key Words : DAC, Developing Country, Maritime Industry, ODA, OECD

\section{1. 서 론}

우리나라는 한국전쟁 이후 국제사회에서 가장 극빈국에 해당하였으며, 1980년대까지 미국의 가장 많은 원조를 받는 국가 중 하나였다. 하지만 1990년대 이후 세계 경제팽창과 더불어 우리나라도 지속적인 경제성장을 거듭하여 2000년대 에는 원조 수원국에서 원조 공여국으로 전환된 세계 유일의 국가가 되었다(Bureau of ODA Policy in the Korean Prime Minister, 2013a). 하지만 이러한 지위 전환과는 달리 여전히

\footnotetext{
* First Author : gyh3445@kst.or.kr, 032-260-2200

† Corresponding Author : minyh@kst.or.kr, 032-260-2287
}

원조 분야에 있어서는 신흥 공여국으로 많은 개선사항을 품 고 있는 국가 중 하나이다. 특히 해사안전과 관련한 공적개 발원조를 살펴볼 경우 그 상황은 더욱 심각하다고 할 수 있 다. 실제로 우리나라는 1960년대 대기업 중심의 경제성장으 로 체제를 전환하면서, 개발도상국에 대한 공여를 시작하였 고 그 역사는 약 50년에 이른다고 할 수 있다(EDCF, 2013). 하지만 그 역사에 비해 해사안전과 관련된 공여 활동 실적 은 거의 전무하다고 해도 과언이 아니다. 특히 우리나라 해 사산업(조선산업 세계 1 위, 해운산업 세계 5 위, 컨테이너 물동 량 세계 5위)의 세계적 위상과 국제사회 위상(국제해사기구 (International Maritime Organization, IMO) A그룹 이사국)을 고 
$\mathrm{OECD}$ 개발원조위원회(DAC) 주요규범 분석을 통한 국내 해양수산 공적개발원조(ODA) 발전방향 연구

려할 때(KSA, 2012), 동 분야에 있어서의 개발도상국 국제협 력은 전무하다고 해도 과언이 아니다.

이에 본 논문에서는 공적개발원조의 의의에 대해서 간략 하게 개관한 후, 국제 및 국내 공적개발원조의 동향을 분석 하고, 공적개발원조에 있어서 국제규범을 살펴본 후 우리나 라 해사안전 관련 공적개발원조의 문제점을 분석하여, 향후 해사산업 분야의 공적개발원조가 나아가야할 방향에 대해 서 제언하고자 한다.

\section{2. 공적개발원조 $(\mathrm{ODA})$ 의의}

\section{1 공적개발원조 $(\mathrm{ODA})$ 의의}

오늘날의 공적개발원조는 국가, 국제기구, 다자은행 등을 포 함하는 공적기관에 의해 OECD DAC(Organization for Economic Cooperation and Development, 경제협력개발기구, 이하 $\mathrm{OECD} /$ Development Assistance Committee, 개발원조위원회, 이하 DAC) 가 정한 개발도상국에 증여율이 $25 \%$ 이상인 양허성 조건의 자금을 수원국의 경제발전과 복지향상을 위해 제공하는 것 을 의미하는 것이다(OECD, 2008; KOICA, 2008).

이러한 공적개발원조는 현재 다자 혹은 양자간 원조로 시 행되고 있으며, 이들 원조는 또한 유상 혹은 무상원조로 나 뉘어 실시되게 된다. 이러한 원조는 그 이행 방법에 따라 또 한 구속성, 비구속성 원조로 나눌 수 있으며, 구속성 원조란 원조자금의 흐름이 공여국으로 환류되어 직·간접적으로 재 화의 흐름이 공여국으로 되돌아오는 원조를 의미하며, 비구 속성 원조란 원조자금의 흐름이 경쟁입찰 등을 통해 자유롭 게 흘러가도록 하는 원조를 의미한다.

\section{2 공적개발원조(ODA) 현황 \\ 1) $\mathrm{OECD} \mathrm{DAC}$ 회원국 공적개발원조(ODA) 현황}

$\mathrm{OECD} \mathrm{DAC}$ 에서는 매년 회원국의 공적개발원조 현황을 집계하여 게시한다. 이는 $\mathrm{UN}$ 이 정한 $\mathrm{ODA}-\mathrm{GNI}$ 비율 $0.7 \%$ 를 달성하기 위해 지속적으로 회원국들을 독려하는 동시에 공 적개발원조 자금의 흐름을 투명화하여 도움이 필요한 국가 에 가장 적절한 원조가 이루어질 수 있도록 하기 위함이다. 전 세계 공적개발원조 규모는 1997년 이후 지속적으로 증가 추세에 있으며, 형태로는 전략적 이유에서 양자간 원조형태 의 증가가 주를 이룬다(OECD, 2012). 일반적으로 공적개발원 조의 질적 수준을 언급할 때에는 무상원조 및 비구속성 원 조의 비율을 참고한다. $\mathrm{OECD} \mathrm{DAC}$ 는 평균적으로 약 $80 \%$ 의 비구속성 원조를 유지하고 있으며, 유상원조는 전체 원조의 $15.4 \%$ 에 불과하다.
Table 1. Volume of ODA in OECD DAC and the Republic of Korea

\begin{tabular}{lrrrr} 
& \multicolumn{4}{c}{ Unit : millions of US dollars } \\
\hline \multicolumn{1}{c}{ Year } & \multicolumn{1}{c}{$\mathbf{2 0 0 9}$} & \multicolumn{1}{c}{$\mathbf{2 0 1 0}$} & $\mathbf{2 0 1 1}$ & \multicolumn{1}{c}{$\mathbf{2 0 1 2}$} \\
\hline $\begin{array}{l}\text { DAC members } \\
\text { total }\end{array}$ & $\mathbf{1 1 9 , 7 7 8}$ & $\mathbf{1 2 8 , 4 6 5}$ & $\mathbf{1 3 3 , 7 1 6}$ & $\mathbf{1 2 5 , 5 8 6}$ \\
Korea & 816 & 1174 & 1325 & 1551 \\
Ratio & $0.7 \%$ & $0.9 \%$ & $1.0 \%$ & $1.2 \%$ \\
\hline
\end{tabular}

Source : OECD Statistics; Development aids, Bureau of ODA Policy in the Korean Prime Minister

\section{2) 우리나라 공적개발원조(ODA) 현황}

공적개발원조 주요정책 및 기본계획 등을 심의하기 위하 여 우리나라는 2006년부터 국무총리실 산하에 국제개발협력 위원회를 두고 개발원조와 관련된 정책, 제도, 추진계획, 평 가 등을 심의하고 있다. 동 위원회의 위원장은 국무총리이 며, 위원은 기획재정부장관, 외교부 장관, 국무총리실장을 포함하는 25 명 이내의 중앙행정기관 혹은 관련 기관, 단체의 장으로 위원장이 위촉하도록 되어 있다. 주요 임무로는 국 제개발협력 기본 계획 및 분야별 연간종합시행계획, 국제개 발협력의 평가에 관한 사항, 국제개발협력과 관련된 정책 중 정부 차원의 조정이 필요한 사항 등이 있으며, 동 위원회 산하 실무회로 국제개발협력 소위원회를 두고 있으며, 평가 및 행정에 관한 실무를 담당하도록 하고 있다.

Table 2. Volumes of ODA from the Republic of Korea

\begin{tabular}{crrrrr} 
& \multicolumn{5}{c}{ Unit : Million USD(net expenditure) } \\
\hline Year & $\mathbf{2 0 0 8}$ & $\mathbf{2 0 0 9}$ & $\mathbf{2 0 1 0}$ & $\mathbf{2 0 1 1}$ & $\mathbf{2 0 1 2}$ \\
\hline \hline Total volume of ODA & $\mathbf{8 0 2 . 3}$ & $\mathbf{8 1 6}$ & $\mathbf{1 , 1 7 3 . 8}$ & $\mathbf{1 , 3 2 5}$ & $\mathbf{1 , 5 5 1}$ \\
Bilateral(a+b) & 539.2 & 581.1 & 900.6 & 990 & 1,162 \\
Grant(a) & 368.7 & 367 & 573.9 & 575 & 696 \\
EDCF(b) & 170.6 & 214.1 & 326.7 & 415 & 466 \\
Multilateral & 263.1 & 234.9 & 273.2 & 335 & 389 \\
ODA/GNI, \% & 0.09 & 0.1 & 0.12 & 0.12 & 0.14 \\
\hline Source : ODA policy and research, Bureau of ODA Policy in the \\
Korean Prime Minister
\end{tabular}

공적개발원조의 정책과 별도로 실제 사업 및 관련 정책은 한국국제협력단(KOICA)과 대외경제협력기금(EDCF)로 나누 어 시행되고 있다. 과거 우리나라 무상원조 중 증여성 원조 는 외교부가 담당하였으나, 기술협력은 다수의 정부 부처 또는 국내기관들에 의해 국제협력차원에서 산발적으로 추 진되었으며, 한국국제협력단(KOICA) 설립 이후 프로젝트, 물자지원, 긴급구호, 개발조사, 연수생초청, 해외봉사단, 민 관협력, 국제기구협력사업 등으로 통합되어 실시되고 있다. 우리나라의 양자간 무상 원조의 전체 원조 규모의 약 $44 \%$ 
를 차지하고 있으며, 수혜국가 및 국제기구는 각 112 개국 및 24개 기구가 있다. '09년도 한국국제협력단 무상원조의 소득 수준별 지원은 중저소득국 $36.5 \%$, 최빈국 $28.3 \%$, 저소득국 $17.9 \%$ 이다(KOICA, 2013).

우리나라 유상원조는 기획재정부 산하에 1987년 설치된 대외경제협력기금(EDCF)을 통해 실시되고 있다. 기금의 관 리는 재정경제부, 운영 및 실무는 한국수출입은행에서 담당 한다. 동 기금의 재원은 정부출연금, 재정·융자 특별회계로 부터의 차입 및 기금운용수익금으로 구성되며, ' 11 년 말까지 의 총조성액은 28,011 억원이다. 차관유형에는 개발사업차관, 기자재차관, 전대차관, 사업준비차관, 해외투·융자대출이 있 으나, 개발사업 및 기자재 차관의 비중이 ' 11 년 기준 $99 \%$ 로 대부분을 차지한다. ' 11 년도 말까지 43개국에서 211 개 개발 사업이 시행되었고, 32,435 억원의 원조자금이 지원되었으며, 지역별로는 아시아지역이 $73.6 \%$ 로 가장 높은 지원을 받았 다(KOICA, 2013).

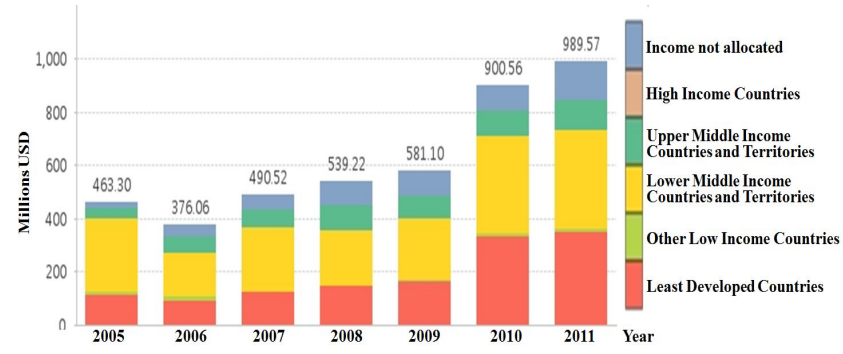

Fig. 1. Bilateral ODA according to groups of national incomes. (Net expenditure, unit : million USD)

Source : Statistics from Korea Eximbank

우리나라 공적개발원조는 양자 유·무상 원조 외에도 다자 간 원조를 실시하고 있으며, 전체 공적개발원조의 약 $25 \%$ 를 차지한다. 다자간 원조는 국제기구 혹은 국제금융기구에 대 한 납부·자본금 출자 등을 통해 이루어지며, 유엔, 국제해사 기구 등 국제기구 분담금 납부는 외교부에서, 국제부흥개발 은행, 국제개발협회, 아시아개발은행 등 국제금융기구에 대 한 출자는 기획재정부에서 담당한다. 주요 수원기관으로는 유엔 및 세계은행이 있으며, 유엔개발계획(United Nations Development Program, UNDP)와도 기본협력 협정을 체결하고 $\mathrm{UNDP}$ 의 비용 분담, 또는 신탁기금 설치를 통한 공동협력사 업을 추진하고 있다(Bureau of ODA Policy in the Korean Prime Minister, 2013c).

우리나라의 공적개발원조 규모는 2006년 이후 지속적인 증가추세에 있으나, 23개 $\mathrm{OECD} \mathrm{DAC} \mathrm{회원국} \mathrm{중에서} \mathrm{여전히}$ 2012년 기준 16번째에 해당하며, GNI대비 원조규모는 2012
년 기준 $0.14 \%$ 로 $\mathrm{UN}$ 권고치 $0.7 \%$ 에 여전히 미달해 있다. 이 는 $\mathrm{OECD} \mathrm{DAC}$ 회원국 평균 $0.31 \%$ 의 $1 / 3$ 보다 낮은 상태이 며, $\mathrm{OECD} \mathrm{DAC}$ 회원국 중 22 번째에 해당하는 수준이다 (Bureau of ODA Policy in the Korean Prime Minister, 2013b). 원 조의 질에서 보면, 유상원조 비율이 2011년에는 $47 \%$ 에 이르 러 앞에서 언급한 $\mathrm{OECD}$ 평균의 약 3 배에 해당하여 유상원 조의 비율을 낮추어야 하는 상황임에 반해, 비구속성원조 비율은 우리나라 전체 원조 대비 $36.1 \%$ 밖에 되지 않아 원 조의 질을 향상시키기 위해서는 비구속성 원조 비율을 확대 해야 하는 상황이다(Shim, 2012).

\section{3. $\mathrm{OECD}$ 개발원조위원회(DAC) 주요규범}

\subsection{OECD 개발원조위원회(DAC) 개요}

$\mathrm{OECD} \mathrm{DAC}$ 는 공여국 정부와 다자국제기구들의 모임으로 빈곤퇴치와 UN천년개발목표(Millennium Development Goals, $\mathrm{MDGs}$ ) 달성을 목적으로 하고 있는 세계 유일의 국제 모임 이다. $\mathrm{DAC}$ 는 $\mathrm{OECD}$ 내부에서 경제개발에 있어서 타국원조에 사용될 수 있는 국가자원 조성방안에 대해 논의하고 장기재 원 흐름 및 새로운 개발원조의 확대 및 향상에 대해 논의하 는 역할을 담당한다.

$\mathrm{DAC}$ 의 최고결정기관은 회원국간의 각료회의이며 여기서 $\mathrm{DAC}$ 와 관련된 중요 정책 사항 및 의사결정이 이루어진다. 이와 더불어 연구와 정책안 마련은 $\mathrm{DAC}$ 산하의 8 개 작업반 이 활동하면서 전문적이면서 심도있는 정책개발이 이루어 진다. 이들 작업반의 업무영역은 매3 4년 주기로 검토되며, 회의 빈도수는 연 1 2회 개최된다. 또한 $\mathrm{DAC}$ 는 $\mathrm{OECD}$ 산하 의 $\mathrm{DCD}($ Development Co-operation Directorate)를 두고 $\mathrm{DAC}$ 의 기술 및 운영에 관한 사무를 맡도록 하고 있다(OECD, 2010).

Table 3. Members of OECD DAC (July, 2013)

\footnotetext{
* Withdrawal in 1974 and rejoin in 1991 ** EC has a status as the secretariat in OECD but not in DAC.
}

\section{$\langle$ Members of DAC〉}

Belgium(1961), Canada(1961), France(1961), Germany(1961), Italy(1961), Japan(1961), Netherlands(1961), Portugal(1961)*, UK(1961), USA(1961), EC(1961)**, Norway(1962), Denmark(1963), Sweden(1965), Austria(1965), Australia(1966), Swiss(1968), New zealand(1973), Finland(1975), Ireland(1985), Spain(1991), Luxemburg(1992), Greece(1999), Republic of Korea(2010), Czech(2013), Iceland(2013), Total 26 members

Source : OECD Development Co-operation Directorate (DCD-DAC) DAC members 
$\mathrm{OECD}$ 개발원조위원회(DAC) 주요규범 분석을 통한 국내 해양수산 공적개발원조(ODA) 발전방향 연구

THE DAC AT WORK

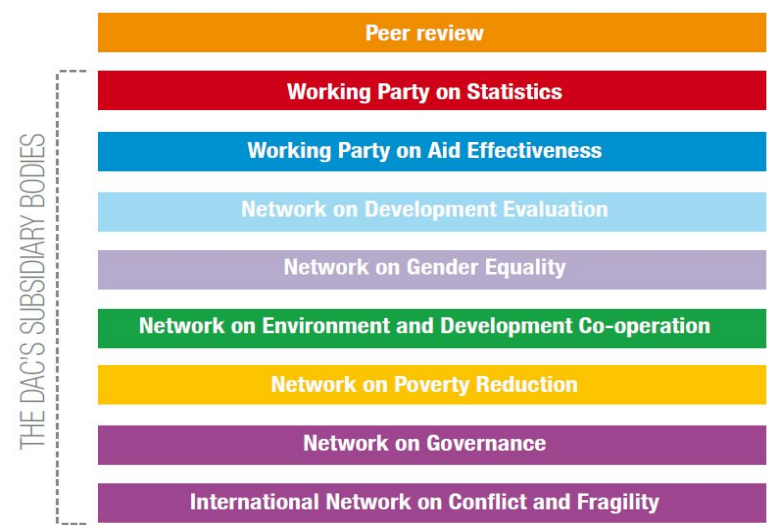

Fig. 2. Organizational chart of OECD DAC.

Source : INSIDE THE DAC; A Guide to the OECD Development Assistance Committee

\section{$3.2 \mathrm{OECD}$ 개발원조위원회(DAC) 주요규범 및 지침 1) 주요규범 및 권고사항}

$\mathrm{OECD}$ 의 규범은 결정(decision), 권고(recommendation), 기타 규범으로 구분되는데, 형식상 회원국의 이행의무를 부여하 는 규범은 결정뿐이며, 권고 및 기타 규범은 'soft law'로써 강제력이 없는 비구속적 규범이다(Kim, 1997). DAC 회원국 으로 준수해야 할 대표적 주요 규범은 다음과 같다.

\section{(1) 1978 년 원조공여조건에 대한 권고}

$\mathrm{DAC}$ 에서는 원조의 범위를 정하고, 통일되고 호혜적인 원 조를 제공하기 위해 1972년 10월 원조에 대한 공여조건을 권 고사항으로 채택하였다. 동 권고는 회원국간 원조의 통일성 을 높이고 원조 증여율의 실질적인 증가를 위해 1978년 3월 개정을 한 차례 하여 지금에 이르고 있다. 동 권고에서 정한 주요 내용은 먼저, 원조공여국의 $\mathrm{ODA}$ 약정액에 대한 평균 증여율(Grant Element)을 최소한 $86 \%$ 로 높이고, 개별 최빈국 에 대한 $\mathrm{ODA}$ 의 증여율을 3 년 평균 $86 \%$ 이상으로 하고, 최 빈국 그룹에 대해서는 연간 $90 \%$ 이상으로 유지해야 한다는 것을 정하고 있다. 그리고 이러한 수치를 회원국이 아무리 만족한다 하더라도, GNI에 대한 $\mathrm{ODA}$ 약정규모 비율이 DAC 회원국 평균보다 현저히 낮은 국가는 목표수준을 달성한 것 으로 간주하지 않는데, 통상 $\mathrm{ODA}$ 약정액/GNI 비율이 회원국 평균의 $75 \%$ 보다 낮은 경우를 의미한다(Kwon, 2009).

(2) 2008년 최빈국에 대한 비구속화 원조 권고

동 최빈국 비구속화 원조 권고안은 향후 이행 상황을 점 검하기 위해 준거치(Reference Indicator Matrix)를 정하고 있는 데, 첫 번째로, 양자간 최빈국 $\mathrm{ODA}$ 의 비구속화 비율로서 최
빈국에 대한 양자간 원조에서 비구속성 원조가 차지하는 비 율로 측정된다. 또한 비구속성 비율이 높더라도 최빈국에 대 한 지원 자체가 일정 정도 이상이 되어야 하는 권고치 또한 설정하고 있다. 두 번째로, 노력분담지수(ESCI : Effort-Sharing Composite Indicator)를 정하고 있는데 이는 다자간 최빈국 원 조로서 비구속화 원조 정도를 의미한다.

\section{2) $\mathrm{DAC}$ 주요 지침 \\ (1) 환경과 개발}

$\mathrm{DAC}$ 에서 합의된 환경관련 주요 지침들은 2001년 지속가 능 발전 전략, 2002년 개발협력으로의 리우협약 통합, 2006 년 전략적 환경평가 적용: 개발협력에 관한 모범 사례 지침 를 들 수 있으며, 첫 번째 지침은 $\mathrm{DAC}$ 의 개발협력과 환경에 있어서 지속가능한 발전전략을 구축하고 시행하는데 모범 이 되는 정책 지침을 국가개발계획, 빈곤전략계획, 국가녹화 계획을 중심으로 제공하기 위해서 작성된 것이며, 두 번째 지침은 기후변화, 생물다양성, 사막화의 세 가지 리우협약 이슈와 빈곤퇴치의 개발의제 간 통합을 위한 방법과 수단을 제시하면서, 범지구적 환경과제와 지속가능한 개발 간의 연 계성 및 두 과제의 통합, 그리고 통합과정에서 공여기관 및 수원국의 역할에 관한 내용을 제시하는 것이며, 세 번째 지 침은 국가정책 및 섹터별 계획, 예산지원 등의 프로그램 수 준에서 사용할 수 있는 환경평가 방법을 제시하면서, 또한 전략적 환경평가의 특성 및 역할, 주요 원칙과 단계, 적용점 과 관련 수단에 관한 내용을 지시하는 것이다.

\section{(2) 무역과 개발}

2001년 4월 채택된 개발에 관한 무역역량강화 지침은 개 발도상국의 무역역량 강화를 통해 이들 국가가 무역자유화 의 혜택을 온전히 누릴 수 있도록 함으로써 다자무역체제에 대한 불신을 줄이는 한편, 해외 원조에 대한 의존도를 낮추 고자 하는 것이다. 동 지침에서는 개발도상국이 직면하고 있는 무역 관련 제약을 크게 국제무역 참여 측면과 경쟁력 측면에서의 제약으로 나누고 이러한 제약을 개선하기 위해, 국가개발전략에 무역과 관련된 전략을 포함토록 하여 이러 한 전략을 실행해 가는 과정에서의 협력, 무역정책을 구체 화하는 과정에의 참여, 무역정책 자체 및 그것을 시행하는 기관의 역량 강화를 추구토록 촉구하고 있다.

\section{(3) 젠더와 개발}

1998년 채택된 개발협력에서의 성평등과 여성권한 부여 에 관한 지침은 $\mathrm{DAC}$ 의 성평등 정책에 근간이 되는 것으로, 성차별과 성 불평등이 사회문화 전반에 걸쳐 뿌리 깊은 근 원을 가지고 있다는 점을 인식하고(Kim et al., 2008), 1995년 
제4차 세계여성회의에서 채택된 베이징 행동강령에 기초하 여 성평등과 여성의 권한부여를 위한 개발원조 정책과 사업 을 개발하는 데 있어 $\mathrm{DAC}$ 와 그 회원국, 수원국의 상호책임 과 의무를 명시하고 있다.

\section{(4) 빈곤과 개발}

2001년 DAC 고위급회의는 그 주제를 빈곤감소와 정책일 관성(Poverty Reduction and Policy Coherence)으로 하여 개최되 었는데, 여기서 빈곤퇴치를 위한 주요 정책을 제시한 빈곤 퇴치에 관한 지침이 채택되었다. 동 지침은 빈곤퇴치를 위 해 공여국과 수원국의 파트너십과 정책 일관성을 강조하면 서, 수원국 정부와 공여국의 원조기관, 국제기구 이외에도 시민사회, 의회 등 다양한 개발주체들의 역할을 제시하고 있다. 또한 동 지침은 일관성 있는 접근법을 위해 각국의 정 책우선순위를 빈곤퇴치로 할 것을 강조하면서, 다음의 여섯 가지 요소를 고려할 것을 강조하고 있다. 첫째는 빈곤층을 위한 성장과 불평등 제거, 둘째는 빈곤층의 역량강화, 인권 및 거버넌스의 구축, 셋째는 인간개발을 위한 기초적 사회 서비스의 제공, 넷째는 취약성 약화 및 충격관리를 내용으 로 하는 인류안보, 다섯째는 성 주류화와 양성평등의 촉진, 여섯째는 환경적 지속가능성이다. 지침은 이와 더불어, 원조 기관의 역할 또한 명시하고 있는데, 가장 기본적인 사항은 각종 개발 프로그램 수립 시 수원국의 국가발전 전략에 기 반을 두어야 한다는 점이다. 즉, 다시말해, $\mathrm{DAC}$ 회원국들은 원조 정책을 전 지구적 빈곤퇴치 목표에 맞게 수립해야 하 며, 수원국에서는 범정부 차원에서 빈곤퇴치 전략을 수립해 야 한다는 것이며, 이와 더불어 무역, 농업, 식량안보, 사회 문제, 분쟁, 환경, 거버넌스, 인간안보 등 모든 분야에서 빈 곤퇴치를 향한 정책일관성을 유지해야 한다는 것이다.

\section{4. 해사안전 공적개발원조(ODA) 개선방향}

\section{1 해사안전 공적개발원조(ODA) 현황}

우리나라 공적개발원조에 있어서 해사안전 및 그 인프라 분야에 대한 지원실적은 한국의 원조가 시작된 이래 아주 간헐적으로 이루어져 왔다. 실제로 해사안전에 관한 기술 혹은 기자재 원조는 다부문적(Cross-cutting) 지원으로 어느 한 분야에 국한하여 추진할 수 없다. 이에 $\mathrm{DAC}$ 의 양자간 원 조 분류 혹은 국제기구에서의 원조 분류 체계에서도 해사안 전이라는 단어는 명시적으로 나타나지 않는다. 이에 해사안 전부문이 대부분 선박의 교통과 관련이 있다는 점을 고려하 여, 전체 규모를 가늠해보기 위해 원조분류에 있어서 $\mathrm{DAC}$ 의 경제인프라에 운송부문을 기준으로 우리나라 원조 현황을 Table 4 와 같이 분석하였다.
Table 4. Volume of bilateral ODA in the Republic of Korea (Net expenditure)

\begin{tabular}{c|c|c|r|r|r}
\hline \multicolumn{1}{c}{$\begin{array}{c}\text { DAC } \\
\text { Category }\end{array}$} & Type & Scope & $\mathbf{2 0 0 9}$ & \multicolumn{1}{c}{$\mathbf{2 0 1 0}$} & \multicolumn{1}{c}{$\mathbf{2 0 1 1}$} \\
\hline \hline & & $\begin{array}{c}\text { Policy and } \\
\text { governance }\end{array}$ & 0.16 & 0.43 & 0.20 \\
& Road & 49.62 & 91.93 & 200.22 \\
$\begin{array}{c}\text { Economic } \\
\text { infrastructure } \\
\text { and services }\end{array}$ & $\begin{array}{c}\text { Transportati } \\
\text { on and } \\
\text { warehouse }\end{array}$ & Rail & 29.20 & 21.09 & 19.46 \\
& Waterway & -4.60 & 2.19 & 9.70 \\
& Air & 3.00 & 1.93 & 0.25 \\
& Warehouse & 0.00 & 0.00 & 0.00 \\
& Total (a) & Traning & 0.00 & 0.00 & 0.00 \\
\hline
\end{tabular}

Source : Statistics from Korea EximBank

Table 4를 기준으로 우리나라 전체 원조에서 운송부문이 차지하는 비중은 2006년 이후 우리나라 개발원조가 본격적 으로 이루어진 이래 지속적으로 증가하고 있다. 하지만, 도 로운송 부문의 원조가 2006년 미화 31백만불에서 2011년 200 백만불까지 급속도로 증가한 것에 비해, 타 운송부문의 지 원은 철도부문이 2011년 19백만불, 수로부문이 9.7백만불, 항 공부문이 0.3 백만불로 운송부문 전체 원조의 $10 \%$ 미만이다. 운송정책 및 행정관리, 운송 창고, 교육 부문과 같이 운송부 문 전체에 걸쳐 지원되는 부문을 제외하고서라도 Table 4에 서 2011년 기준 도로 운송 부문 지원이 약 $87 \%$ 나머지 철 도, 수로 항공 운송 지원 부문이 약 $13 \%$ 에 지나지 않는다. 실제 시행된 원조 프로젝트별 실적을 보면 그 양상은 더욱 심각하다고 할 수 있다.

우선 해상안전 혹은 선박과 관련된 $\mathrm{EDCF}$ 의 양자원조 실 적을 살펴보면, 2006년에 시행된 방글라데시 재난구조선 구 매사업 원조가 미화 약2천 6백만불 (원화 28,933백만원) 기자 재차관으로 이루어졌으며 이후에는 2010년에 들어서야 세네 갈에 대한 해상인프라 구축사업 원조가 개발사업차관으로 이루어졌다. 2011년과 2012년에도 재난구조선 구매사업(보 충)이 2006년에 집행되었던 방글라데시 원조 사업의 후속추 가 사업으로 계획되었고, 이와 더불어 해상안전운항시스템 구축사업 원조가 계획되었지만, 현재까지 집행된 원조금액 은 없는 것으로 우리나라 ODA 통계를 관리하는 $\mathrm{EDCF} \mathrm{ODA}$ 통계시스템에서 확인하였다. 또한 $\mathrm{KOICA}$ 의 양자 무상원조 사업을 살펴보면, 현재까지 프로젝트 형 사업으로 해양안전 과 관련해 이루어진 원조사업은 2007년 2008년에 걸쳐 약 
40만불 규모로 시행된 알제리 선박안전성 제고 사업이 전부 인 것으로 확인된다. 그외 전문가인력 파견 사업으로 2012년 인도네시아에 한국선급의 선박검사 전문가 1 명이 해상안전 확보를 위한 선박검사 자문을 수행하고 있으며, 2012년과 2015년에 필리핀 및 인도네시아를 대상으로 해상교통시스템 및 선박안전에 관한 무상원조 프로젝트 사업이 진행될 계획 이지만 현재까지 집행된 금액은 없는 것으로 확인되고 있다.

현재, 국제사회는 대형 해난사고 방지를 위해 안전사고 규제 강화 및 기술개발, 안전에 대한 패러다임 전환 등을 꾀 하고 있다. 이러한 안전사고에 대한 국제적인 동향은 향후 직접적으로는 안정적인 사회인프라 구축을 통한 국가의 지 속가능 개발을 지원하고, 안정적인 사회자본을 구축함으로 국민들의 사회간접자본에 대한 접근성을 향상시킬 것으로 예상되고 있다. 하지만 이러한 국제 동향과는 별개로 우리 나라 해사안전 공적개발원조의 지원 실적 및 동향은 미미하 기만 하다. 이에 다음 장에서는 해사안전관련 공적개발원조 현황에 대한 문제점 파악해보고 동 분야의 원조 증가를 위 한 개선사항 및 발전방향에 대해 검토해보도록 한다.

\section{2 해사안전 공적개발원조(ODA) 개선방향 1) 중 - 장기 계획 수립 필요}

현재 우리나라 공적개발원조에 있어서 해양수산분야의 지위는 앞에서도 살펴본 바와 같이 그 국제적 위상에 비해 미미하기만 하다. 실제 건설 인프라와 관련된 항만 건설 분 야를 제외하고는 명시적으로 해양수산을 하나의 분야로 명 시한 개발원조 계획 혹은 국별 협력전략, 중점 협력분야는 찾아보기 힘든 것이 사실이다. 이는 다양한 이유가 존재하 겠지만, 제일 우선은 해양수산분야에 있어 공적개발원조에 대한 중·장기 추진 계획 부재로 인한 것으로 사료된다. 이에 향후 체계적인 해사안전 분야 공적개발원조 사업 발굴 및 규모확대를 위해서는 관련 부처내 내 해양수산부문 공적개 발원조의 중·장기 계획이 수립되어야 할 것으로 판단되며, 아래에서는 이러한 계획 수립을 위해 고려되어야 할 사항을 제언하고자 한다.

먼저, 해양수산관련 공적개발원조 중·장기 계획 수립에 고려되어야 할 사항은 $\mathrm{OECD} \mathrm{DAC}$ 국제규범을 고려한 국제 공적개발원조 시스템과의 조화를 들 수 있다. 우리나라는 2012년 OECD DAC로부터 우리 공적개발원조에 관한 동료검 토를 받은 바 있다. 동 동료검토는 $\mathrm{OECD} \mathrm{DAC에} \mathrm{가입한} \mathrm{회}$ 원국들을 대상으로 타 동료 회원국들이 일정간격으로 공적 개발원조 시행에 관한 시스템 및 활동들을 $\mathrm{OECD} \mathrm{DAC} \mathrm{규범}$ 을 토대로 평가하는 것이다. 동 동료검토 결과에서는 우리 나라 원조의 질적 향상을 위해 원조의 비구속화 비율 증대, 분절화된 원조를 연계하는 프로그램 원조의 증대, 효과성
개선을 중심으로 국내 원조기관과 관련 전문가의 효율적 활 용 및 역량강화 등을 지적하고 있다.

실제 우리나라 해양수산 분야 원조 사업은 $90 \%$ 가 구속성 원조에 해당하며, 양식기술이전 등을 제외하고는 대부분 단 발성 사업에 그치고 그 효과를 측정하기 어려우며, 단위사 업 당 수행기관이 다양한 반면 동 분야의 단위 사업들을 총 괄관리하는 협의체의 부재로 인해 사업 분절화가 심각하다 고 할 수 있다. 특히, 해사안전부문 원조의 경우 지속 경제 개발의 기반이 되는 기술자 양성 직업훈련 등과 같은 적정 기술 이전보다 우리나라에서 건조한 재난방재선 제공, 재활 용 어선 공급 등 단순 제품 원조에만 집중되어 있어, $\mathrm{DAC}$ 에 서 권고하고 있는 개발도상국 인력의 사업참여를 통한 원조 사업 주인의식 강화, 혹은 자력 경제활동을 위한 기술역량 강화 교육 등은 이루어지지 않고 있다고 할 수 있다. 결국 이는 $\mathrm{OECD} \mathrm{DAC}$ 동료검토를 통해 지적된 원조의 질 저하로 이어지고 있으며, 궁극적으로는 원조의 효과성 저하로 귀결 된다고 할 수 있다. 이에 $\mathrm{OECD} \mathrm{DAC}$ 의 동료검토 결과를 반 영하고, 국제 원조와 조화되는 장기적 해양수산 분야 공적 개발원조의 개발을 위해서는 중·장기 계획 수립을 통한 프로 그램 원조가 필수적이라 할 수 있다.

프로그램 원조는 개발도상국의 경제개발 정책을 고려하여, 그 국가에 필요사항을 검토하고, 국제기구 혹은 타국 원조와 비교하여, 우리나라가 우위에 있는 분야에 대해 장기적인 계 획을 수립하여 원조를 실시하는 것을 말한다. 결국, 동 프로그 램의 원조를 위해서는 우리나라 주요 협력 개발도상국을 대상 으로 그들의 필요를 파악하고, 향후 우리나라 해양수산 부문 원조의 영향을 분석하여 실질적으로 필요한 개발부문에 인적, 물적, 지식적, 기술적 부문에 대한 통합 원조를 실시하기 위한 거시적인 중·장기계획이 수립되어야 한다고 할 것이다.

\section{2) 해양수산 통합 ODA 추진 필요}

앞에서 언급한 바와 같이 $\mathrm{DAC}$ 는 동료검토를 통해 회원 국들의 $\mathrm{OECD} \mathrm{DAC}$ 규범 실현 정도를 평가하고 그 결과에 따른 권고를 제공한다. 우리나라 또한 2012년 동 동료검토 를 통해, 원조체제 및 시행의 분절화, 효율성 부족, 원조규 모의 확충과 관련된 권고를 제공받은 바 있다. 동 권고에서 특히 주목해야 할 것이 원조의 분절화다. 분절화는 각각의 원조 사업이 유기적으로 연계되어 수원국 전체 경제개발에 실질적인 영향을 미치기보다 하나의 사업으로서 종료되는 경우를 말한다. 해양수산 분야 공적개발원조의 경우, 양식 혹은 수산 자원 개발 관련 원조, 해상 교통 인프라 기술 원 조, 연안환경관리 혹은 연안삼각주 관리사업 등이 주를 이 루고 있다. 이들 사업들은 형식상 개별사업으로 분류되어 있지만, 실제 사업 목적 달성을 위해서는 사업간 유기적인 
연결이 필요하다. 다시 말해, 원조의 실효성은 빈곤 퇴치 혹 은 삶의 질 향상에 있으므로 양식 혹은 수산 자원 개발을 통해 지속적인 식량재원 및 단백질 제원을 확보하여 기아 를 해소하는 것으로 달성할 수 있을 것으로 보여진다. 하지 만 실질적인 수산 자원개발을 위해서는 개발의 도구가 되 는 해상교통 인프라의 구축이 필수적이다. 수산자원 채취 및 개발은 선박이라는 도구를 통해 이루어지고 선박이라는 도구를 활용하기 위해서는 이를 안전하게 이용하기 위한 관련 해양시설 및 안전관리 인프라가 구축되어야 하는 것 이다. 또한 지속적인 수산 자원 개발을 위해서는 연안환경 관리가 필수적이고 이를 위한 장기적인 제도 및 정책 또한 수립되어져야 한다.

우리나라의 경우 1996년 통합 해양행정기관 설립 이후 연 안환경관리, 연안어획물 등 수자원 관리, 어선 등 선박 및 관련 시설 관리가 통합적으로 이루어지고 있어 하나의 유기 적인 형태로 운영, 관리되어지고 있다고 할 수 있다. 하지만, 정작 원조의 경우, 개별 전문 분야의 유관기관이 사업을 수 행함으로 원조 목적 실현을 위한 통합시스템 원조사업이 이 루어지기보다 개발된 사업이행을 위한 단위사업이 이루어 지고 있다고 할 것이다. 이러한 사업 이행은 장기적인 사업 절차 이행을 통해 궁극적으로 이루어지는 목적 달성이 어려 우며, 단기성과 및 과업 이행에 중점이 조정되어 있어 향후 후속 사업을 통한 수원국의 실질적인 경제개발을 실현하기 어려운 경우가 많다. 결국 $\mathrm{OECD} \mathrm{DAC} \mathrm{및} \mathrm{우리나라} \mathrm{해양수산}$ 분야 원조의 효과성 및 목적의 실질적 달성을 위해서는 분 절적으로 이루어지는 이들 사업의 유기적인 연계 및 통합이 이루어져야 할 것이다. 이를 위해서는 해양수산분야 원조의 중·장기 계획도 수립되어야 하겠지만, 사업의 중복성 및 분 야별 범위에 대한 분석·조정이 필요할 것이다. 그리고 이러 한 분석·조정을 위해서는 관련 기관의 사업 정보공유 기반 이 마련되어져야 할 것이므로 관련 기관별 협의체 혹은 컨 소시엄 등 구성도 고려되어져야 할 것이다.

\section{5. 결 론}

우리나라 공적개발원조는 2006년 이후 지속적으로 확충 되어 그 양적증가에 있어 2012년 현재 2006년 대비 약 3 배 를 초과달성하는 성장을 이루고 있다. 하지만, 이러한 성장 과는 별개로 우리 정부는 개발원조에 대한 또 다른 성장을 계획하고 있으며, 이는 2010년 $\mathrm{OECD} \mathrm{DAC} \mathrm{가입시} \mathrm{공언한}$ 것으로 그 규모를 2015년에 이르러는 현재 우리나라 GNI 대비 $0.25 \%$ 까지 증적하여 $\mathrm{OECD} \mathrm{DAC}$ 의 회원국으로서 공적 개발원조에 대한 역할을 다할 것이라는 것이다. 이를 위해 우선적으로 우리나라는 현재 시행중인 공적개발원조 정책
및 제도 평가를 $\mathrm{OECD}$ DAC 동료검토를 통해 2012년 실시하 였으며, 그 결과에 따른 개선사항을 $\mathrm{OECD} \mathrm{DAC로부터} \mathrm{권고}$ 받은 바 있다.

동 동료검토를 기반으로 해양수산 관련 공적개발원조의 문제점을 파악해 보면, 우선적으로 해양수산 분야 공적개발 원조의 중·장기 계획 부재를 들 수가 있을 것이다. 현재 공 적개발원조의 동향은 프로그램 기반 원조 및 분절화 해소를 통한 원조의 효과성 제고라고 할 수 있다. 즉, 원조의 효과 성을 제고하고, $\mathrm{OECD} \mathrm{DAC}$ 의 공적개발원조 관련 국제규범 과 조화된 원조 실현을 위해서는 관련 분야 중·장기 계획 수 립이 필수적이라 할 수 있을 것이다.

다음으로 해양수산 분야 공적개발원조 개선을 위해서는 각 단위 사업별 분절화를 해소해야 한다는 것이다. 사업의 분절화는 해양수산 분야의 단위 사업들이 서로 연계되지 않 고 개별적으로 진행됨으로 행정 및 사업경계상 중복사항이 발생하여 불필요한 재원이 투자 되고, 거시적 관점에서 개 발도상국 경제개발 기반 확보를 통한 원조의 실효성 확보가 이루어지지 않는 것을 의미한다. 따라서 이러한 분절화 해 소를 통해 사업의 효과성을 제고하기 위해서는 국토교통부 의 인프라개발 협의체, 외교부의 개발협력연 대(Development Alliance, Korea, DAK)와 같이 분야별 유관기관 협의체 등을 구성하여 관련 수행중인 공적개발원조 사업정보를 공유하 고, 향후 컨소시엄 구성 등을 통해 통합 사업 수행 등을 고 려해야 할 것이다.

\section{References}

[1] Bureau of ODA Policy in the Korean Prime Minister(2013a), History of Korea's ODA, Webpage of Korea's ODA (www.odakorea.go.kr).

[2] Bureau of ODA Policy in the Korean Prime Minister(2013b), ODA policy and research : Report for statistical information on ODA of OECD and the Republic of Korea, Webpage of Korea's ODA(http://www.odakorea.go.kr/hz.blltn.PolicySl.do? blltn_div=oda\&bltn_seq=152\&brd_seq=9).

[3] Bureau of ODA Policy in the Korean Prime Minister(2013c), Volume of ODA in the Republic of Korea, Webpage of Korea's ODA(www.odakorea.go.kr).

[4] EDCF(2013), History of ODA, Korea Eximbank (http://www. edcfkorea.go.kr/edcf/intro/oda/history_1960.jsp).

[5] Kim, S. H.(1997), Soft Law in the international law, Korea International Law Review, Vol. 8, pp. 21-42.

[6] Kim, Y. H., H. S. Jeong, S. H. Kwak and J. Y. Kim(2008), Main streaming Gender for Development: Analysis on Korea's 
$\mathrm{OECD}$ 개발원조위원회(DAC) 주요규범 분석을 통한 국내 해양수산 공적개발원조(ODA) 발전방향 연구

Development Assistance, Korean women's Development Institute 2008 Research Paper 21, pp. 17-18.

[7] KOICA(2013), Korea's ODA, Webpage of KOICA (http://www.koica.go.kr/).

[8] KOICA(2008), Understanding International Development Cooperation, Seoul: Hanulbooks, pp. 30-33.

[9] KSA(2012), Annual Report on the Shipping in 2011, Korea Shipowners' Association, pp. 48-51.

[10] Kwon, Y., Y. H. Kim, S. K. Park, T. J. Lee, H. J. Lee, Y. A. Jeong, J. S. Jeong, J. W. Jeong, H. S. Jeong, M. J. Cho, S. H. Choi and J. G. Han(2009), "OECD DAC Accession and its Implications for Korea's ODA Policy”, KEIP Research Paper 09-11, pp. 56-57.

[11] OECD(2012), "2012 DAC Report on Multilateral Aid". available at http://www.oecd.org/dac/aid-architecture/DCD DAC(2012)33_FINAL.pdf (Last visited on 17 June, 2013), pp. 6-8.

[12] OECD(2010), "INSIDE THE DAC; A Guide to the OECD Development Assistance Committee", Paris: OECD. pp. 1-11.

[13] OECD(2008), "Is it ODA?", Paris: OECD, pp. 1-4.

[14] Shim, J. K.(2012), Capacity of ODA should be extended but the ratio of the loan assistance have to be decreased, Newspaper of Asia Economy(http://www.asiae.co.kr/news/ view.htm?idxno=2012101012490915100). p. 1.

원고접수일 : 2013년 12월 26일

원고수정일 : 2014년 02월 26일 (1차)

2014년 03월 03일 (2차)

게재확정일 : 2014년 04월 25일 